\title{
MANAJEMEN PENDIDIKAN INKLUSI DI SEKOLAH DASAR SUMBERSARI 1 KOTA MALANG
}

\author{
Ina Agustin \\ FKIP, Universitas PGRI Ronggolawe Tuban \\ Email: inaagustin88@gmail.com
}

\begin{abstract}
Abstrak. Penyelenggaraan pendidikan inklusi merupakan suatu sistem layanan pendidikan khusus yang mensyaratkan agar semua anak berkebutuhan kbusus mendapatkan layanan pendidikan di kelas yang sama bersama siswa reguler. Penelitian ini bertujuan untuk mengetahui implementasi manajemen pendidikan inklusi dan kendala yang dihadapi dalam implementasi manajemen pendidikan inklusi di SDN Sumbersari 1 Malang. Penelitian ini menggunakan metode deskriptif kualitatif. Teknik pengumpulan data meliputi: observasi, wawancara dan dokumentasi. Subyek penelitian adalah kepala sekolah, wali kelas, guru pembimbing khusus dan orang tua murid. Hasil dari penelitian ini menunjukkan bahwa: 1) Implementasi dari manajemen pendidikan inklusi dapat dilihat dari jumlah siswa berkebutuhan khusus pada tahun ajaran 2015/2016 berjumlah 19 orang, mempunyai 2 (dua) tenaga guru pembimbing khusus, serta kurikulum yang sudah dimodifkasi menurut kebutuhan peserta didik. 3) Kendala dari program pendidikan inklusi adalah pembiayaan pendidikan, dan beberapa sarana dan prasarana belum memadai serta kurangnya tenaga guru pendamping.
\end{abstract}

Keywords: Manajemen, Pendidikan Inklusi, Anak Berkebutuhan Khusus

\begin{abstract}
Implementation of inclusive education is a system that requires special education services for all children with special needs to get education in the same classes alongside regular students. This study aims to determine the implementation of inclusive education management and the obstacles encountered in the implementation of inclusive education management in SDN Sumbersari 1 Malang. This study used descriptive qualitative method. In collecting data, the researcher used data collection techniques include: observation, interviews and documentation. The Subjects of research were principals, homeroom, a special guidance counselor and parents. The results of this study show that: 1) The implementation of inclusive education management can be seen from the number of students with special needs in 2015/2016 academic period are 19 people, has 2 (two) special supervising teachers, and the curriculum has been modified according to the needs of students, 3) The obstacle encountered in the study was the funding of education, and some inadequate facilities and infrastructure as well as the lack of teacher assistant.
\end{abstract}

\section{Keyword: Management, Inclusive education, children with special needs}

\section{PENDAHULUAN}

Dunia pendidikan Indonesia mengalami banyak permasalahan, mulai dari pemberantasan buta-huruf, angka putus sekolah, kenakalan remaja, hingga peluang untuk mendapat kesempatan yang sama dalam pendidikan, terutama untuk para penyandang disabilitas. Amanat UU Sisdiknas Nomor 20 Tahun 2003 Pasal 5, Ayat 1 menyebutkan bahwa "Setiap Warga Negara mempunyai hak yang sama untuk memperoleh pendidikan yang bermutu."1 Lebih lanjut, Ayat 2 berbunyi "Warga Negara yang memiliki kelainan fisik, 
emosional, mental, intelektual, dan social berhak memperoleh pendidikan khusus." Pasal 11 Ayat 1 berbunyi, "Pemerintah pusat dan pemerintah daerah wajib memberikan layanan dan kemudahan, serta menjamin terselenggaranya pendidikan yang bermutu bagi setiap warga negara tanpa diskriminasi." Sedangkan pada Ayat 2 disebutkan bahwa "Pemerintah pusat dan pemerintah daerah wajib menjamin tersedianya dana guna terselenggaranya pendidikan bagi setiap warga negara yang berusia tujuh sampai dengan lima belas tahun.

Undang-Undang di atas menunjukkan bahwa semua warga negara usia sekolah mempunyai hak untuk memperoleh pendidikan yang bermutu, serta layanan pendidikan untuk semua (education for all). Pendidikan inklusi merupakah salah satu upaya pemerintah untuk mewujudkan hal tersebut. Secara umum, pendidikan inklusi merupakan pendidikan yang mengakomodasi semua peserta didik tanpa mempedulikan keadaan fisik, intelektual, sosial, emosi, bahasa atau kondisi lainnya termasuk anak penyandang cacat. Pendidikan inklusi menempatkan anak berkelainan tingkat ringan, sedang dan berat secara penuh di kelas reguler, dalam kelas yang sama, demi mewujudkan penyelenggaraan pendidikan yang menghargai keanekaragaman dan tidak diskriminatif.

Pendidikan inklusi merupakan pendidikan yang berusaha mengakomodasi segala jenis perbedaan dari peserta didik, termasuk anak berkebutuhan khusus. Secara konseptual dan paradigmatis, pendidikan inklusif menurut Farrell (2008) memiliki karakter akomodatif, dengan menerima setiap siswa dan menghindari labeling negatif, serta dalam operasionalnya melibatkan pihakpihak terkait secara aktif.

Berdasarkan Peraturan Menteri Pendidikan Nasional No. 32 tahun 2008 tentang standar kualifikasi akademik dan kompetensi guru pendidikan khusus, pendidikan inklusi merupakan pendidikan yang memberikan kesempatan bagi peserta didik berkebutuhan khusus karena kelainan fisik, emosional, mental, intelektual, sosial, dan atau memiliki potensi kecerdasan dan bakat istimewa untuk belajar bersama-sama dengan peserta didik lain pada satuan pendidikan umum maupun kejuruan, dengan cara menyediakan sarana, tenaga pendidik, tenaga kependidikan dan kurikulum yang disesuaikan dengan kebutuhan individual peserta didik.

Dewasa ini pendidikan inklusif menunjukkan perkembangan kuantitatif yang pesat. Dalam rangka mendukung penyelenggaraan program pendidikan inklusi di kota Malang, maka Dinas Pendidikan Pemuda dan Olahraga Provinsi Jawa Timur menginstruksikan kepada Dinas Pendidikan Kota Malang untuk menunjuk sekolah penyelenggaraan pendidikan inklusi. Salah satu sekolah dasar di Kota Malang yang ditunjuk sebagai sekolah penyelenggara pendidikan inklusi adalah SDN Sumbersari 1 Kota Malang.

Berdasarkan hasil wawancara dengan kepala sekolah SDN Sumbersari 1 Kota Malang menyatakan bahwa pada tahun 2002 SDN Sumbersari 1 Malang sudah mempunyai siswa yang termasuk dalam kategori anak berkebutuhan khusus (ABK). Tetapi karena belum ada penunjukan sebagai sekolah dasar yang menyelenggarakan pendidikan inklusi dari pemerintah terkait maka pelaksanaan pendidikan dan pemberian fasilitas untuk siswa ABK masih diperlakukan sama dengan siswa regular yang lain. Setelah ada penunjukan sekolah penyelenggara pendidikan inklusi dari Dinas Pendidikan Kota Malang pada tahun 2004. Maka SDN Sumbersari 1 Kota Malang menjadi sekolah dasar negeri yang menyelenggarakan pendiidkan inklusi.

Meskipun sudah banyak Sekolah Dasar yang ditunjuk sebagai sekolah inklusi, tetapi dalam implementasinya masih banyak yang tidak sesuai dengan konsep-konsep yang mendasar, bahkan tidak jarang ditemukan adanya kesalahan kesalahan praktek terutama terkait dengan aspek 
pemahaman, kebijakan internal sekolah, kurikulum, serta tenaga kependidikan dan pembelajarannya. Permasalahan di atas tentu saja menarik untuk diteliti lebih lanjut. Oleh sebab itu penelitian ini bertujuan untuk mengetahui beberapa aspek penting terkait dengan pelaksanaan dan kendala pendidikan inklusi di SDN Sumbersari 1 Malang.

\section{a. Konsep Manajemen Pendidikan}

Manajemen merupakan kegiatan atau rangkaian kegiatan yang dilakukan dari, oleh dan bagi manusia (Nurhadi, 1983:2). Rangkaian kegiatan itu merupakan suatu proses pengelolaan dari suatu rangkaian kegiatan pendidikan yang sifatnya kompleks dan unik yang berbeda dengan tujuan perusahaan untuk memperoleh keuntungan yang sebesar-besarnya. Manajemen pendidikan pada prinsipnya merupakan suatu bentuk penerapan manajemen atau administrasi dalam mengelola, mengatur dan mengalokasikan sumber daya yang terdapat dalam dunia pendidikan. Hal ini senada dengan pernyataan Nurhadi (1983:5) yang menyatakan bahwa manajemen pendidikan adalah suatu ilmu yang yang mempelajari penataan Sumber Daya Manusia (SDM), kurikulum, atau sumber belajar dan fasilitas untuk mencapai tujuan pendidikan secara optimal dan menciptakan suasana yang baik bagi manusia, yang turut serta dalam pencapaian pendidikan yang telah disepakati.

\section{b. Pendidikan Inklusi}

Pendidikan inklusi adalah suatu ideologi, sistem dan atau strategi dalam penyelenggaraan pendidikan, di mana anakanak berkebutuhan khusus memperoleh layanan pendidikan dalam lingkungan belajar yang sama bersama anak-anak lainnya, secara bermutu dan sesuai dengan kebutuhannya.

Konsep ini telah menjadi isu besar saat ini dalam dunia pendidikan, baik di tingkat nasional maupun international. Sejumlah deklarasi telah banyak dilansir, baik pada tingkat nasional maupun internasional yang mendorong dan menekankan pentingnya pendidikan inklusi bagi anak-anak berkebutuhan khusus.

Secara konseptual, model pendidikan inklusi menjanjikan sejumlah keunggulan dalam penyelenggaraan pendidikan bagi anak berkbutuhan khusus. Pendidikan inkluisi dianggap merupakan strategi yang efektif untuk menuntaskan wajib belajar 9 tahun, bagi anak-anak berkebutuhan khusus. Hal ini dimungkinkan karena anak dapat memperoleh pendidikan pada sekolah manapun yang terdekat dengan rumah tinggalnya. Di sisi lain, model ini juga dianggap lebih efisien karena tidak perlu mendirikan sekolah khusus untuk mereka. Pendidikan inklusif juga lebih memungkinkan siswa berkebutuhan khusus melakukan pembelajaran emosi dan sosial secara lebih wajar. Di sisi lain, model ini juga mendorong siswa lain untuk belajar menghargai dan menerima anak-anak berkebutuhan khusus (Smith, 2006).

Gallagher (1986) memberikan uraian yang lebih rinci tentang berbagai model penyelenggaraan pendidikan inklusi bagi anak berkebutuhan khusus, yaitu:

\section{a. Pure Inclusion (inklusi penuh)}

Pada model ini Anak Berkebutuhan Khusus (ABK) memperoleh layanan pendidikan dan pembelajaran di kelas-kelas reguler secara bersama-sama dengan anakanak yang lain. Anak Berkebutuhan Khusus (ABK) mendapatkan layanan pendidikan yang sesuai dengan kemampuan dan kebutuhannya. Kurikulum, materi, proses serta evaluasi pembelajaran benar-benar dirancang dan dijalankan sesuai dengan kondisi anak.

\section{b. Consultant Teacher (Guru Konsultan)}

Pada model ini Anak Berkebutuhan Khusus (ABK) belajar pada sekolah reguler terdekat dimana anak tinggal. Lebih dari 50\% waktu belajar diberikan (dilakukan) oleh guru biasa pada sekolah setempat. Guru konsultan adalah guru khusus (guru SLB) yang berfungsi sebagai konsultan bagi guruguru, kepala sekolah atau petugas lainnya 
yang ada di sekolah reguler. Pada program ini, guru konsultan mungkin menggunakan sebagaian kecil waktunya untuk melakukan proses belajar mengajar secara langsung dengan Anak Berkebutuhan Khusus (ABK). c. Itinerant Teacher (Guru Keliling)

Program ini memiliki karakteristik yang hampir sama dengan program guru konsultan, yaitu Anak Berkebutuhan Khusus (ABK) belajar pada sekolah-sekolah biasa terdekat. Yang membedakannya dengan guru konsultan adalah bahwa pada program guru keliling, guru khusus (guru SLB) menggunakan sebagaian besar waktunya untuk melakukan pengajaran langsung kepada Anak Berkebutuhan Khusus (ABK). d. Resource Room Program (Kelas Sumber Belajar)

Anak Berkebutuhan Khusus (ABK) terdaftar pada suatu sekolah biasa (umum), dimana terdapat di dalamnya suatu kelas khusus yang digunakan untuk melaksanakan pengajaran khusus bagi Anak Berkebutuhan Khusus (ABK). Pengajaran di kelas sumber kurang lebih menggunakan separo dari keberadaan waktu belajar Anak Berkebutuhan Khusus (ABK) di sekolah. Keberadaan kelas sumber menjadi faktor pendukung yang penting dan strategis bagi pelaksanaan pengajaran yang diadakan di kelas regular, khususnya untuk mengatasi kondisi dan kebutuhan khusus yang dialami Anak Berkebutuhan Khusus (ABK). Pengajaran di kelas khusus dilakukan oleh guru pembimbing khusus (GPK).

e. Special Class (Kelas Khusus)

Anak Berkebutuhan Khusus (ABK) terdaftar dalam sebuah kelas khusus yang ada pada sekolah reguler. Pengajaran pada kelas ini biasanya relatif padat/penuh dan berlangsung sepanjang jam (jam sekolah). Program yang disajikan biasanya berkenaan dengan pengembanan materi atau keterampilan-keterampilan khusus yang dibutuhkan. Program ini memungkinkan Anak Berkebutuhan Khusus (ABK) untuk sewaktu-waktu ikut serta ke dalam kelas reguler pada bidang-bidang tertentu sesuai dengan kebutuhan dan minat.

f. Special Class (Sekolah Khusus)

Model ini berbentuk lembaga sekolah yang secara khusus diperuntukkan bagi Anak Berkebutuhan Khusus (ABK). ini merupakan model penyelenggaraan pendidikan yang benar-benar terpisah dari program pendidikan umum (reguler). Model ini dikenal dengan istilah Sekolah Luar Biasa (SLB). Ada dua tipe dari model ini yaitu sistem harian (day school) dan sekolah berasrama (residensial school). Dalam model sekolah harian (day school), anak Anak Berkebutuhan Khusus (ABK) tinggal di rumah orang tuanya, mereka pergi dan pulang sekolah setiap hari, sedangkan dalam sistem residensial school Anak Berkebutuhan Khusus (ABK) tinggal di asrama yang merupakan bagian terpadu dari sekolah.

\section{METODE}

Metode yang digunakan dalam penelitian ini adalah metode deskriptif kualitatif. Penelitian kualitatif adalah "Suatu pendekatan penelitian yang mengungkapkan stuasi sosial tertentu dengan mendeskripsikan kenyataan secara benar, dibentuk oleh katakata berdasarkan teknik pengumpulan data dan analisis data yang relevan yang diperoleh dari situasi yang alamiah" (Djam'an dan Komariah, 2010:25).

Penelitian ini dilaksanakan di SDN Sumbersari 1 Kota Malang. Subyek penelitian dipilih berdasarkan tujuan tertentu dari peneliti. Subyek penelitian ini meliputi: 1 orang kepala sekolah, 3 orang guru kelas, 2 guru pembimbing khusus, dan 2 orang tua murid sekaligus sebagai anggota paguyuban wali murid ABK. Teknik pengumpulan data dan informasi dalam penelitian kualitatif ini menggunakan teknik observasi, wawancara dan kajian dokumentasi. Setelah data terkumpul kemudian peneliti menganalisisnya secara kualitatif. 
HASIL DAN PEMBAHASAN

\section{a. Pelaksanaan manajemen pendidikan di SDN Sumbersari 1 Kota Malang}

Hasil penelitian menunjukkan pelaksanaan manajemen pendidikan di SDN Sumbersari 1 Malang dalam bidang :

\section{1) Kurikulum}

Guru kelas bekerja sama dengan guru pembimbing khusus (GPK) telah memodifikasikan kurikulum sesuai dengan kemampuan dan karakteristik peserta didik. Kurikulum yang digunakan dalam penyelenggaraan pendidikan inklusi pada dasarnya menggunakan kurikulum reguler yang berlaku di sekolah umum yaitu kurikulum 2013 untuk kelas 1, 2, 4, dan 5. untuk kelas 3 dan 6 masih menggunakan kurikulum KTSP.

Bentuk modifikasi kurikulum yang dilakukan berupa mengakomodasi indikator siswa regular menjadi bentuk yang lebih sederhana disesuaikan dengan kemampuan anak berkebutuhan khusus. Namun karena keragaman hambatan yang dialami peserta didikberkebutuhan khusus sangat bervariasi, masih ada beberapa materi pembelajaran dalam kurikulum yang disesuaikan dengan siswa reguler.

\section{2) Peserta didik}

Peserta didk berkebutuhan khusus pada tahun ajaran 2015/2016 di SDN Sumbersari 1 Kota Malang berjumlah 19 orang. Yang terdiri dari jenis kebutuhan tunagrahita, slow leaner, disleksia, dan hiperaktif (ADHD). Adapun sistem penerimaan peserta didik dilakukan secara penyuluhan/promosi. Hal ini sesuai dengan pendapat Imron (2012:44) yang menyatakan bahwa sistem promosi adalah penerimaan peserta didik, yang sebelumnya tanpa menggunakan seleksi. Karena itu, mereka yang mendaftar menjadi peserta didik, tidak ada yang ditolak. Persyaratan umum dalam penerimaan peserta didik berkebutuhan khusus di SDN Sumbersari 1 malang adalah mengutamakan ABK yang jarak tempat tinggalnya dengan sekolah lebih dekat serta jumlah peserta didik berkebutuhan khusus maksimal $10 \%$ dari jumlah siswa regular di kelas.

\section{3) Kegiatan Pembelajaran}

Berdasarkan hasil observasi dan wawancara kepada guru kelas dan guru pembimbing khusus secara umum kegiatan pembelajaran di kelas bersifat fleksibel. Peserta didik berkebutuhan khusus yang pada kondisi stabil dapat bersama-sama mengikuti penbelajaran di kelas regular. Guru kelas sebagai penghandel pembelajaran secara klasikal untuk siswa regular sedangkan peserta didik berkebutuhan khusus di bombing oleh guru pembimbing khusus.

Peserta didik berkebutuhan khusus yang pada kondisi tidak stabil, bisa mengikuti pembelajaran di ruang sumber bersama guru pembimbing khusus (GPK) dan sementara waktu keluar dari kegiatan pembelajaran di kelas reguler.

4) Hubungan Sekolah dan Masyarakat

Menurut pengamatan peneliti berdasarkan hasil observasi dan wawancara kepada wali murid ABK bahwa ikatan sosial antara orang tua murid sangat tinggi. Pad saat pertemuan dengan komite beberapa orang tua siswa menyumbang alat bantu seperti pengadaan buku dan alat music angklung yang digunakan pada kegiatan ekstrakulikuler peserta didik berkebutuhan khusus.

\section{Kendala yang Dihadapi dalam}

\section{Pelaksanaan Pendidikan Inklusi}

1) Pembiayaan Pendidikan

Berdasarkan hasil observasi dan wawancara kepada kepala sekolah terkait dengan pembiayaan penyelenggaraan pendidikan inklusi didapatkan bahwa pembiayaan masih kurang maksimal. Terkait hal ini pihak sekolah memberikan alasan karena belum teralokasikan dana untuk penyediaan sarana dan prasarana sekolah. Untuk memenuhi pengadaan sarana dan prasarana khusus untuk peserta didik berkebutuhan khusus dilakukan pengajuan 
proposal ke dinas pendidikan dan pemerintah terkait.

Dalam rangka penyelenggaraan pendidikan inklusi, perlu dialokasikan pembiayaan khusus, yang antara lain untuk keperluan: (1) Kegiatan assesmen input siswa. (2) Modifikasi kurikulum. (3) Insentif bagi guru pembimbing khusus.

Pengadaan sarana-prasarana. (6) Pelaksanaan kegiatan belajar-mengajar.

2) Tenaga Guru Pembimbing Khusus

Tenaga guru pembimbing khusus di SDN Sumbersari 1 Malang berjumlah 2 orang dengan kualifikasi lulusan psikologi pendidikan dan pernah mengikuti pelatihan pendidikan inklusi dari berbagai lembaga.

Tugas guru pembimbing khusus yaitu:

a) Menyelenggarakan assesmen dan administrasi khusus untuk peserta didik berkebutuhan khusus.

b) Menyelenggarakan kurikulum modifikasi dan pengembangan program untuk peserta didik berkebutuhan khusus.

c) Menyelenggarakan layanan pembelajaran khusus dengan melakukan adaptasi media, menyediakan alat bantu khusus dan sumber belajar khusus yang dibutuhkan untuk meningkatkan hasil belajar peserta didik.

d) Menyelengarakan kunjungan rumah untuk mengetahui secara langsung perkembangan peserta didik berkebutuhan khusus

3) Sarana dan Prasarana

Sarana prasarana khusus untuk peserta didik berkebutuhan khusus di SDN Sumbersari 1 Kota Malang adalah tersedianya ruang sumber. Ruang sumber terdiri dari bagian ruang bimbingan, ruang belajar khusus, ruang istirahat yang dilengkapi dengan alat permainan edukatif. Media pembelajaran serta perlengakapan kegiatan ekstrakulikuler seperti alat musik piano, gitar dan angklung juga ditempatkan di ruang sumber. Ruang sumber digunakan untuk mendukung terselenggaranya pembelajaran yang maksimal dan bermakna bagi perkembangan peserta didik berkebutuhan khusus. Kendala dalam pengadaan sarana dan prasarana terkait dengan masih kurangnya sarana prasarana untuk kegiatan proses terapi bagi peserta didik berkebutuhan kbusus.

\section{SIMPULAN}

Simpulan dari kegiatan penelitian ini adalah

a. Program kepala sekolah dalam menyukseskan pendidikan inklusi di SDN Sumbersari 1 Malang merupakan program yang sangat penting dan program tersebut didukung oleh semua staf di SDN Sumbersari 1 Malang.

b. Pendidikan inklusi ini diharapkan dapat memberikan kontribusi yang besar kepada anak berkebutuhan khusus dalam bidang pendidikan, jadi tidak ada lagi anak berkebutuhan khusus yang tidak mendapatkan layanan pendidikan di sekolah.

c. Terkait dengan implementasi program pendidikan inklusi SDN Sumbersari 1 Malang kurikulum yang diterapkan merupakan kurikulum modifikasi yang disesuaikan dengan jenis kebutuhan peserta didik berkebutuhan khusus. kegiatan pembelajaran bersifat fleksibel sesuai dengan kondisi peserta didik berkebutuhan khusus.

d. Kendala yang dihadapi dalam menyelenggarakan pendidikan inklusi adalah jumlah guru pembimbing khusus yang masih kurang dibandingkan jumlah peserta didik berkebutuhan khusus yang ada di SDN Sumbersari 1 Malang.

\section{DAFTAR PUSTAKA}

Imron, A. 2012.Manajemen Peserta Didik Barbais Sekolah, Jakarta: Bumi Aksara.

Satori, D. dan Aan K.2010.Metodelogi Penelitian Kualitatif, Bandung: CV.Alfabeta, 
Setyosari, P.2012.Metode Penelitian

Pendidikan dan Pengembangan, Jakarta: Prenada Media Group

Smith, J. D.2009.Inklusi: Sekolah Ramah

Untuk Semua, Bandung: Nuasa 